\title{
Batılılaşma Dönemi Osmanlı Mimarı̆ı̆ında Bir İktidar İmgesi: Balkon
}

\author{
Emre KOLAY ${ }^{1}$
}

Öz

$\mathrm{Bu}$ çalışmada, Tanzimat'ın ilanı sonrasında değişen yönetim pratikleriyle birlikte mevcudiyetine ve inşasına intiyaç duyulan kamu yapılarının tasarımlarında tercih edilen balkonlar hem mimari hem de sembolik yönüyle değerlendirilecektir. İç mekân ile dış dünya arasında bir geçiş görevi üstlenen balkon tasarımlarının aynı zamanda 19. yüzyıl Osmanlı siyasetinde bir iktidar imgesi olarak okunabilirliği, farklı olay ve durumlar için düzenlenen dönem merasimlerinde kamu eserlerinin rolü üzerinden irdelenecektir. Modernitenin değiştirdiği dünya siyaseti içerisinde önemli bir yere sahip olan iktidar imgeleri, yüzyıllardır var olan simgeler dünyasını yeniden şekillendirebildiği gibi, yeni gelenek ve imge yaratımını da ortaya çıkarmıştır. Bu bağlamda, 19. yüzyıl Osmanlı siyasetinde, kitabe, tuğra ve sancak gibi yüzyıllardır var olan meşruiyet gereçlerinin kullanım alanları artmakla birlikte, arma-i Osmani gibi bu yüzyıl içinde üretilmiş semboller de imgeler dünyasına katılmıştır. Elbette imgelerin en görünür olduğu alanlar 19. yüzyıl içinde inşa edilen kamu yapılarıdır. Belediye, hükümet konağı, saat kulesi, idadi, karakol, postane, hastane gibi pek çok kamu eserlerinin üzerinde iktidar imgelerini görmek mümkündür. Bununla birlikte kimi kamu eserlerinde söz konusu imgelerin toplandığı mekân olarak balkonların tercih edildiği söylenebilir. Bununla birlikte balkonlar, dış dünyaya açtığı odanın işlevi bağlamında da ayrı bir öneme sahiptir. Genel olarak balkon tasarımlarının ana cephe merkezine yerleştirildiği, balkona sahip odaların ise o kamu eserinin en üst düzey yöneticisine ait olduğu görülmektedir. Bu durumda balkon gerek parmaklıkları ve duvarlarında taşıdığı semboller gerekse plan tasarımındaki konumu itibariyle iktidarın meşruiyet imgesi olarak karşımıza çıkmaktadır.

Anahtar Kelimeler: Osmanlı Mimarisi, Kamu Yapıları, İmge, Balkon

\section{Balcony: An Image of Power in Ottoman Architecture during the Westernization Period}

\begin{abstract}
In this study, the balconies, which are preferred in the designs of public buildings that need their existence and construction, together with the changing management practices after the proclamation of the Tanzimat, will be evaluated both architecturally and symbolically. The legibility of balcony designs, which serve as a transition between the interior and the outside world, as an image of power in 19th century Ottoman politics will also be examined through the role of public works in period ceremonies organized for different events and situations. The images of power, which have an important place in the world politics changed by modernity, have not only reshaped the world of symbols that have existed for centuries, but also revealed the creation of new traditions and images. In this context, in the 19th century Ottoman politics, while the usage areas of legitimacy tools such as inscription, tugra and sanjak that have existed for centuries have
\end{abstract}

\footnotetext{
${ }^{1}$ Hatay Mustafa Kemal Üniversitesi, Fen-Edebiyat Fakültesi, Sanat Tarihi Bölümü, Hatay, Türkiye İlgili yazar/Corresponding author: ekolay@mku.edu.tr
} 
increased, symbols produced in this century such as the Arma-i Osmani (state symbol) have also joined the world of images. Of course, the areas where images are most visible are public buildings built in the 19th century. It is possible to see images of power on many public works such as the municipality, government office, clock tower, high school, police station, post Office and hospital. However, in some public works, it can be said that balconies are preferred as the place where these images are collected. In general, it is seen that the balcony designs are placed in the center of the main façade, and the rooms with balconies belong to the highest level manager of that public work. In this case, the balcony appears as the legitimacy image of power, both in terms of the symbols it carries on its railings and walls, and its position in the plan design.

Keywords: Ottoman Architecture, Public Buildings, Image, Balcony

\section{Giriş}

1839'da ilan edilen Tanzimat Fermanı, Osmanlı İmparatorluğu'nun yaşamış olduğu en kritik dönemeçlerden birini oluşturmaktadır. Fermanın ilanı sonrasında değişim gösteren yönetim mekanizmaları kısa zaman içinde pek çok kurumun kurulmasını sağlamış, merkezden taşraya değin merkezi bir yönetim politikası benimsenmiştir. Yapılan veya yapılması planlanan tüm reform girişimlerine genel olarak bakıldığında devletin daha görünür ve her tabana hitap eden bir aygıta dönüştüğü söylenebilir. Devletin görünürlüğü meselesi pek çok alt sorunsallar ve çözüm arayışlarını da beraberinde getirmiştir. Öncelikle oluşturulan yeni kurumların intiyaç duydukları fiziki mekân karşıı̆ı̆ında büyük kentlerden en ufak kasabalara kadar inşa edilen kamu yapıları, devletin varlığını ve gücünü belgeleyen en önemli unsurlar olarak karşımıza çıkarlar. Cülus, açılış, bayram vb. kutlama ve merasimlerin 19. yüzyıl içinde yaygınlaşması ve belli kurallar nezdinde icra edilmesi iktidarın otoriter gücünü pekiştirmek adına ayrı bir önem kazanmıştır. Tanzimat sonrası yaygınlık kazanan bu uygulamaların Hobsbawm'ın öne sürdüğü “icat edilmiş gelenekler" tanımlaması ile örtüştüğü görülmektedir (Hobsbawm, 2013, s.2). Bu yüzyılda değişen devlet algısı, devleti tanımlama ve kitlelere kabul ettirme ya da başka bir değişle "meşruiyet kazanma" isteği yeni devlet geleneklerinin de ortaya çıkmasını sağlamıştır. Gelenek icadı meselesinin sadece Osmanlı İmparatorluğu'na özgü olmayıp, aslında 19. yüzyılda varlığını sürdüren Rusya, Avusturya-Macaristan, Japonya gibi devletler için de önemli bir iktidar sorunsalı oluşturduğu söylenebilir (Deringil, 1999, s.17).

Yapı stokundaki artışa ve inşa faaliyetlerindeki ilgiye bakıldığında Osmanlı hükümeti tarafından mimari faaliyetlerin devletin temsili açısından önemli bir alan olarak görüldüğü yorumunu yapmak mümkündür. Kamu yapılarının işlevi, kütle ve konum özellikleri ile cephe hareketliliği sağlayan üslup ve bezeme biçimleri bağlamında bir iktidar imgesi okumak olanaklı gözüküyor. Kentin en geniş meydanını çevreleyen ve kütle özellikleriyle kent siluetini etkileyen söz konusu yapıların, kitabe, arma, tuğra gibi doğrudan iktidara gönderme yapan simgelerle bir "iktidar imgesi"ne dönüştüğünü söylemek mümkündür. Bu çalışmada, Tanzimat Fermanı sonrasında inşa edilmiş kamu yapılarının balkon tasarımları, "iktidar imgesi" bağlamında irdelenecek, balkonların konumu, kütlesel özellikleri ve içinde barındırdığı simge unsurlarıyla birlikte bir iktidar imgesi olarak ne derece okunabilir olduğu dönemin görsel kaynakları eşliğinde tartışılacaktır.

\section{Osmanlı Mimarlığında Balkon Tasarımları}

İtalyanca balcone kökenine sahip olan balkon (Tietze, 2002, s.273 ve Nişanyan, 2004, s.39) 19. yüzyıldan itibaren Osmanlı mimarlık literatüründe kabul görmüştür. Söz konusu terim Türkiye'de çıkan farklı sözlüklerde birbirine yakın anlamlar içermekte ve balkonun 
dışa açılımı noktasında ortak bir ifade geliştirmektedirler. Bu bağlamda Celal Esad Arseven'in 1906/07 yılında çıkardığı Istılâhât-ı Mi'mariyye adlı mimarlık sözlüğünde balkon maddesinde şu ifadeler geçmektedir: Pencerelerin önünde dışaruya doğru çıkan korkuluklu veya parmaklıklı terase ki açık şahnişin dahi denilebilür (Arseven, 2017, s.43). Arseven, bu ifadesinde balkonu konut mimarlığında sıklıkla karşılaştığımız şahnişin ile değerlendirmekte ve dışa taşkın fakat kapalı bir birim olan şahnişinin açık hali olarak yorumlamaktadır. Sözen ve Tanyeli'nin Sanat Kavram ve Terimleri Sözlüğü adlı eserlerinde balkon maddesinde şu ifadelere yer verilmiştir: Yapıda giriş katın üzerindeki katlarda yer alan, dışa çıkıntı ya da içe doğru girinti biçiminde ve en az bir yönden dış mekâna açılan bölüm (Sözen ve Tanyeli, 2011, s.44). Sözen ve Tanyeli, balkonun sadece cepheden taşan bir birim olmadığını, aynı zamanda cephede oluşturulan girintilerin de balkon olarak değerlendirildiğini vurgulamaktadır. Hasol, Ansiklopedik Mimarlık Sözlüğü adlı eserinde balkon maddesi için şu açıklamayı yapmaktadır: Bir binanın üst katlarından dışarıya doğru çıkmış, önü ve yanları korkulukla çevrili yer (Hasol, 2010, s.67). Hasol'un bu açıklaması balkonu yalnızca dışa taşkınlığı bağlamında değerlendirmesi açısından Sözen ve Tanyeli'den farklı, fakat Arseven'in açıklamasına daha yakın bir konuma yerleştirmektedir. Netice itibariyle balkonun yapı kütlesine bağımlı bir eleman olduğunu, özel/mahrem alan ile kamusal alan arasında bir geçiş elemanı olarak değerlendirilebileceğini söyleyebiliriz. 19. yüzyıl Osmanlı mimarisinde balkon tasarımlarının dışa taşkınlığı sebebiyle cumba ve şahnişin gibi konut mimarisinde yaygın olarak tercih edilen kapalı mekânlarla sık sık mukayese edildiği görülmekte, modern anlamda kent planlamasını arzulayan Osmanlı iktidarının bu amaçla çıkardığı Ebniye nizamnamelerinde de bu karşılaştırma göze çarpmaktadır (Şenyurt, 2018, s.376). Örneğin, 1859 yılında çıkartılan "Zokaklara Dair Nizamname"nin 32. bendinde şahnişin ve balkonlara saksı vb. eşyaların asılmasının yasak olduğu bildirilir. Konut ile sokak dokusu arasındaki ilişkileri düzenleyen nizamnamelerde balkon ifadesiyle birlikte yukarıda Celal Esad'ın da sözlügünde vurguladığı gibi "kapalı balkon" terimi de kullanılmakta ve cumba/şahnişin işaret edilmektedir. Şenyurt, aynı yıllarda arşiv kayıtlarında "cumba" teriminin de kullanıldığını dile getirmektedir. Özel bir alanı teşkil eden şahnişin, cumba ya da balkonların biçimiyle ilgili hükümetin nizami bir sokak görünümü yaratmak amacıyla müdahalede bulunması, özel alan/kamusal alan sınırlarının Osmanlı dünyasındaki muğlak durumunu da açığa çıkarmaktadır (Şenyurt, 2016, s.91). Bu muğlak tavra karşın balkon tasarım ve kullanım biçimlerinin daha net irdelenebilmesi bakımından bu çalışmada, konut, otel vb. özel mülkiyet alan içinde inşa edilmiş balkon tasarımları ile devlet eliyle yapılmış kamu binalarında uygulanan balkon tasarımları iki alt başlık içinde değerlendirilecektir.

\subsection{Sivil mimaride balkon}

Yapı kütlesinin sokak, bahçe vb. açık ve kamusal alana taşması bağlamında Osmanlı konut mimarisinde çözüm cumba ve şahnişin gibi yapı elemanları tarafından sağlanmaktadır. Yerasimos, İslam kentinde kamusal alanın olmadığından söz eder ve özel mülkiyet ile sokak arasındaki özel alan/kamusal alan ilişkisini sokağın ortak alan olarak kullanımı çerçevesinde değerlendirir (Yerasimos, 2012, s.516-518). Burada, özel mülk olan hanenin cumba gibi ana kütleden çıkıntı sağlayan elemanlar ile ortak kullanım alanı olan sokaktan devşirdiği/kopardığı birimler üzerinden özel alan-kamusal alan ayrımının İslam kenti içindeki muğlak durumuna dikkat çekilmektedir. Bu tutum, 16. yüzyıldan 19. yüzyıla değin kent içindeki hane inşasında uyulması gereken kuralları belirten belgelerden rahatlıkla izlenebilmektedir. Özel alan-kamusal alan arasında geçişken bir kimliğe sahip olan sokağı sık sık "işgal eden" cumba ve şahnişin gibi dışa taşkın fakat kapalı birimlerin yanında geç dönem Osmanlı mimarlığında balkonların cephe tasarımlarında yavaş yavaş yer aldığı ve özellikle 19. yüzyılın ikinci yarısından itibaren kimi yapı grupları için vazgeçilmez bir birim olarak kullanıldıkları görülmektedir. Balkonlar, konut mimarisinde cumba ve şahnişin ile birlikte cephe tasarımında yerini 
alırken, otel ve apartman gibi birbirinden bağımsız dairelere sahip yapılarda yaygın bir kullanım alanı bulmuştur. Yüzyılın ikinci yarısında yapısal bağlamda kabuk değiştiren ve Avrupai bir siluet yakalayan Galata/Pera bölgesinde inşa edilen apartman ve otellerin balkon tasarımlarının, sokak dokusuna katkı sağlayacak düzeyde detaylandırılmakta olduğu gözlemlenebilir (Foto 1). Aynı dönemde inşa edilen konut ve yalılarda da balkon kullanımının ağırlık kazandığı görülür. Bu bağlamda özellikle Boğaziçi'nde inşa edilmiş yalıların cephelerine yerleştirilen balkonlar kimi zaman Neoklasik kimi zaman Art Nouveau üslubu içinde şekillenmiştir.

Sivil mimaride karşımıza çıkan balkonların yapım sürecinde farklı malzeme kullanımının olduğu görülmektedir. Ahşap ve tuğla malzeme yaygın bir kullanıma sahip olmakla birlikte özellikle korkuluklarda ve konsollarda metal malzeme tercihi de gözlemlenebilir. 19. yüzyılın sonlarında İstanbul'un sivil mimarisinde sıklıkla tercih edilen Art Nouveau üslubunun kendi imzasını sunduğu en önemli yapı elemanlarının kapı, pencere ve balkon gibi dışa açılım sağlayan birimler olduğu görülür. Özellikle balkon korkuluklarındaki ferforjeler, kıvrımları ve bitkisel süslemeleri ile ön plana çıkmaktadır. Bununla birlikte balkon açıklıklarının cephenin simetrik tasarım anlayışı çerçevesinde değerlendirildiği, oluşturduğu girinti-çıkıntılar ve merkez-köşe alanlara yerleşimleri ile cephenin ritmik hareketliliğine katkı sağladığı izlenmektedir.

Sivil mimaride balkon kullanımının işlevsel bir özelliğe sahip olduğu da söylenebilir. Bu bağlamda balkon içinde yerleştirilen masa, sandalye gibi günlük kullanım eşyaları ile nizamnamelere dahi konu olan saksı gibi bitki yetiştirmeye yönelik malzemelerin yerleşimi, balkonların gündelik ev yaşamında önemli bir yere sahip olduğunu kanıtlamaktadır. 20. yüzyılda Türkiye'nin hızla apartmanlaşma sürecine girmesiyle birlikte balkonlar kentlilerin gündelik yaşamında önemli bir yer edinmeye başlamış, buna paralel olarak balkon tasarımları da çeşitlilik kazanmıştır. Bununla birlikte Şenyurt, Osmanlı İstanbul'unda balkonların yalı ve köşk yapıları haricinde kalan konut mimarisinde oldukça kısıtlı işleve sahip olduğunu vurgular. Gündelik yaşam alanı olmasından ziyade, balkonlar hava almak ve doğayı seyretmek için kullanılan mekanlardır (Şenyurt, 2018, s.370-371).

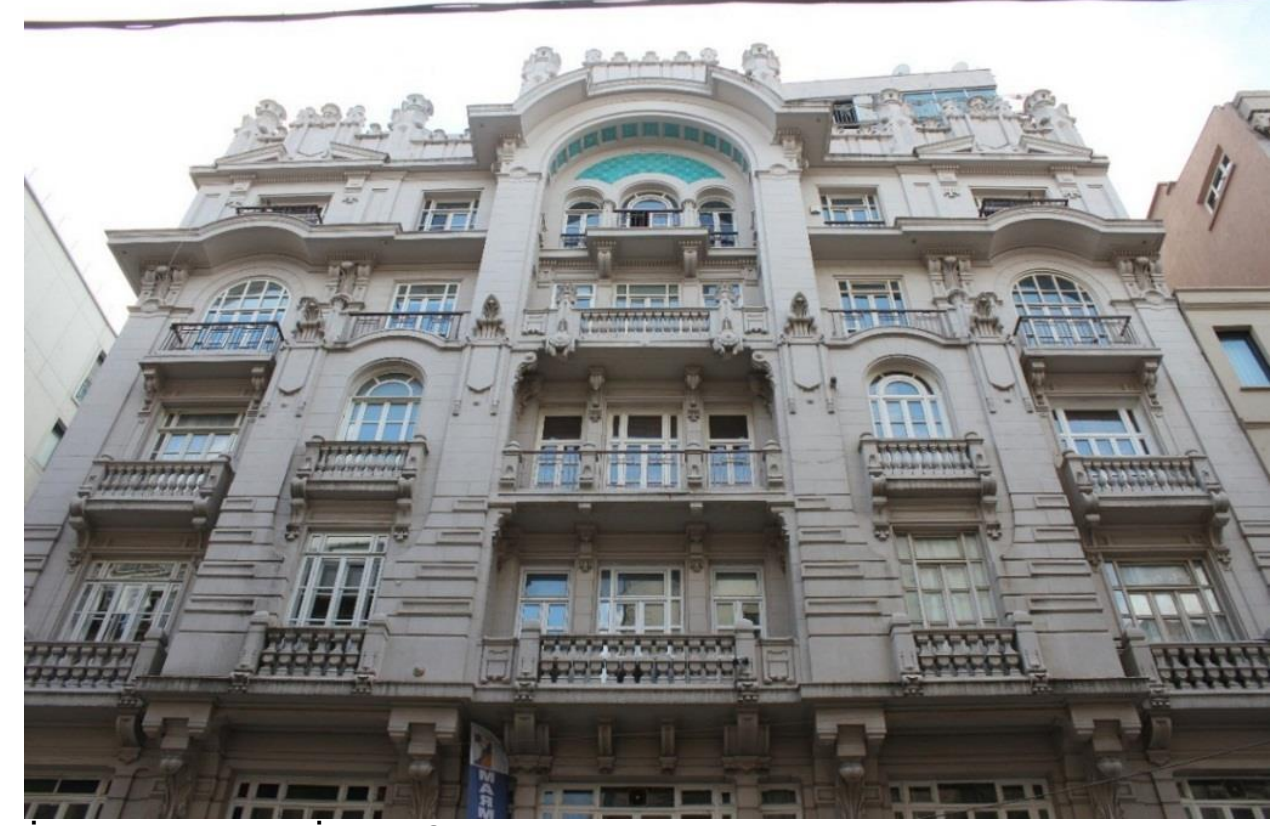

Foto 1. İstanbul, Beyoğlu, İstiklal Caddesi üzerinde konumlanan 1910 tarihli Mısır Apartmanı'nın cephe tasarımına hâkim olan balkon tasarımları. (Emre Kolay, 2018) 


\subsection{Kamu yapılarında balkon}

Tanzimat'ın ilanı sonrasında merkezileşme yöneliminin gittikçe hız kazanması yeni kurum ve kuruluşların ortaya çıkmasına zemin hazırlamıştır. 19. yüzyılın ikinci yarısında henüz oluşturulan bu kurumlar kısa zaman içinde tüm taşra vilayetlerine yayılmış, bu durum beraberinde fiziki mekân intiyacını da doğurmuştur. Bu ihtiyaca yönelik alınan tedbirler de farklılık göstermektedir. Vilayet merkezlerinde inşa edilen hükümet konaklarının çoğu zaman birbirinden farklı kurumlara da ev sahipliği yapan binalar olduğu görülür (Yazıcı Metin, 2019, s.31). Mekân intiyacını karşılamaya yönelik bir diğer girişim ise mahaldeki uygun bir konutun kiralanması olmuştur. Bunlarla birlikte genelde kent merkezinde ve hükümet konağının yakın civarında yeni bir binanın inşası ile mekân sorunu çözülmeye çalışılmaktadır. Böylelikle kimi kentlerde hükümet konağı odaklı bir "hükümet sitesinin" yaratıldığı izlenmektedir. Kamu yapılarının cephe tasarımlarında ise birbirinden farklı tasarım anlayışlarının varlığı gözlenebilir. Genellikle Neo-klasik üslubun tercih edildiği yapılar ile birlikte Oryantalist, Neo-Rönesans ve Neo-Gotik gibi farklı tarihselci üslupların da tasarım sürecine dâhil edildiğini, kimi örneklerde de kırsal mimari dokuyla eşdeğer bir üslup yöneliminin işlediğini söyleyebiliriz. Cephelerde dışa açılımı sağlayan kapı, pencere ve balkon elemanlarının simetrik ve ritmik bir düzen içerisinde tasarlandığı izlenmektedir.

Kamu yapılarında balkon mekanlarının biçimsel özelliklerine bakıldığında ağırlıklı olarak kargir malzeme ve dikdörtgen bir şemaya sahip olduğu izlenebilmektedir. Balkon korkuluklarında ise tercih edilen malzemenin genellikle cephe karakterine uygun olduğu görülür. Bununla birlikte balkon korkuluğunda ahşap ve metal malzeme de tercih edilmiştir. Selanik, İzmir, Yafa ve Kula belediye daireleri ile Manisa Adliye dairesinde uygulanan balkon korkulukları metal malzemeye sahip örnekler olarak sıralanabilir. Konsollar ile desteklenerek çıkıntı oluşturan balkon tasarımları genellikle yapıların cephe merkezlerine yerleştirilmiştir. Bununla birlikte yan cephelerin de balkonla dışa açıldığı örnekler bulunmaktadır. Samsun Hükümet Konağı'nın cephe tasarımları balkonun her cephede tercih edilmesine örnek gösterilebilir. Balkonun tüm cepheyi kaplayan örnekler var olmasına karşın çok sınırlıdır. Manisa belediye dairesi balkonun tüm cephede uygulanmasına bir örnek olarak sunulabilir. Nadir de olsa balkon tasarımının çıkma yerine gömme biçiminde de cepheye uygulandığı örnekler mevcuttur. Taşköprü Askerlik Dairesi bu tip balkona bir örnek teşkil eder.

Kamu yapıları bağlamında dışa açılımı sağlayan ve genellikle cephe merkezine yerleştirilen balkon tasarımlarını hükümet konakları özelinde Gümülcine, Mersin, Razlık, İslâhiye, Niksar, Beyrut, Siroz, Alasonya, Tekfurdağı (Tekirdağ), İzmir, Adana, Mudanya (Foto 2), Samsun, Sivas, Erzurum ve Ergani hükümet konakları örneklerinden izleyebiliriz. Bununla birlikte hükümet konaklarının ana cephe merkezlerinin bir cumba çıkmasıyla vurgulandığını takip edebildiğimiz örnekler de mevcuttur. Aydın, Sinop, Eskişehir, Erzincan (Foto 3), Refahiye, Giresun, Taşköprü, Prizren, Çorum, Bartın, Isparta, Karahisar-ı Sahib (Afyonkarahisar), Bolu, Edirne ve Amasya hükümet konakları gibi örneklerde cephe merkezlerinin cumba ile hareketlilik kazandığı gözlemlenebilir. Belediye binalarında cephe tasarımına eklemlenen balkon örneklerine Samsun (Foto 4), İzmir, Selanik, Trabzon, Yafa, Kula, Alaşehir, Manisa, Limni, Aden, Şam, Jezzine, Tokat, Malkara, Çorlu, Edirne, Tekfurdağı (Tekirdağ), Kadıköy ve Fatih belediye binalarında rastlamaktayız (Kolay, 2018, s.389-390). 20. yüzyılda yaşanan çeşitli toplumsal hareketlerin önemli tanığı olan ve çalışmamız kapsamında ayrıca değerlendirilen Kadıköy ve Fatih belediye binaları bu bağlamda özgün bir konuma sahiptir. Balkon tasarımlarının cephe merkezlerinde tercih edildiği bir diğer yapı grubunu Redif binaları oluşturmakta, özellikle askerlik şube binaları ile depo binalarında balkon kullanımı yaygınlık kazanmaktadır. Bu duruma askerlik şube binası başlığında örnek olarak Ordu, Çal, Sındırgı, Tefenni, Seyitgazi, Ilgın, Bolvadin, Kalecik ve Taşköprü askerlik şube 
binaları sıralanabilir. Askeri depo olarak Daday, Akdağmadeni, Ayancık, Kütahya, Soma, Eşme ve Uzunköprü askeri depo binaları cephe tasarımında balkonların tercih edildiği yapılar arasındadır (Özgen, 2016, s.68,79,81,85,86,90,93-100-103-104,109,116,119$120,133)$. Eğitim yapıları arasında da balkon tercihinin yaygın olduğunu söyleyebiliriz. Bu bağlamda Manisa, Konya, Bursa (Foto 5), Edirne, Drama, Siroz ve Selanik İdadi binaları, Kırkkilise (Kırklareli) İbtidaisi, Konya Mekteb-i Sanayi, Kirmasti Mektebi, Kastamonu Rum Mektebi, Yanya İnas Rüşdiye Mektebi, Trabzon Askeri Rüşdiyesi, Bursa Mekteb-i Askeriye, Sultanahmet Baytar Mektebi, Bursa Hamidiye Ziraat Mektebi ve Diyarbakır Hamidiye Sanat Mektebi ana cephe merkezlerinde balkon tasarımına rastlanan eğitim yapılarına örnek olarak sunulabilir (Yılmaz, 2007, s.20,112,120,123,166,190,205,213-214,234,243,245-246,252,277,282). Hastane ve hapishane binalarında balkon kullanımına nispeten daha az rastlanmaktadır. Florina, Urfa ve Isparta hastaneleri ile Sultanahmet Tevkifhanesi (Foto 6) ve Sultanyeri hapishanesi balkon tasarımlarının uygulandığı yapılar olarak örneklenebilir (Kolay, 2021, s. 233, 271; Sarı, 2021, s. 89-90).

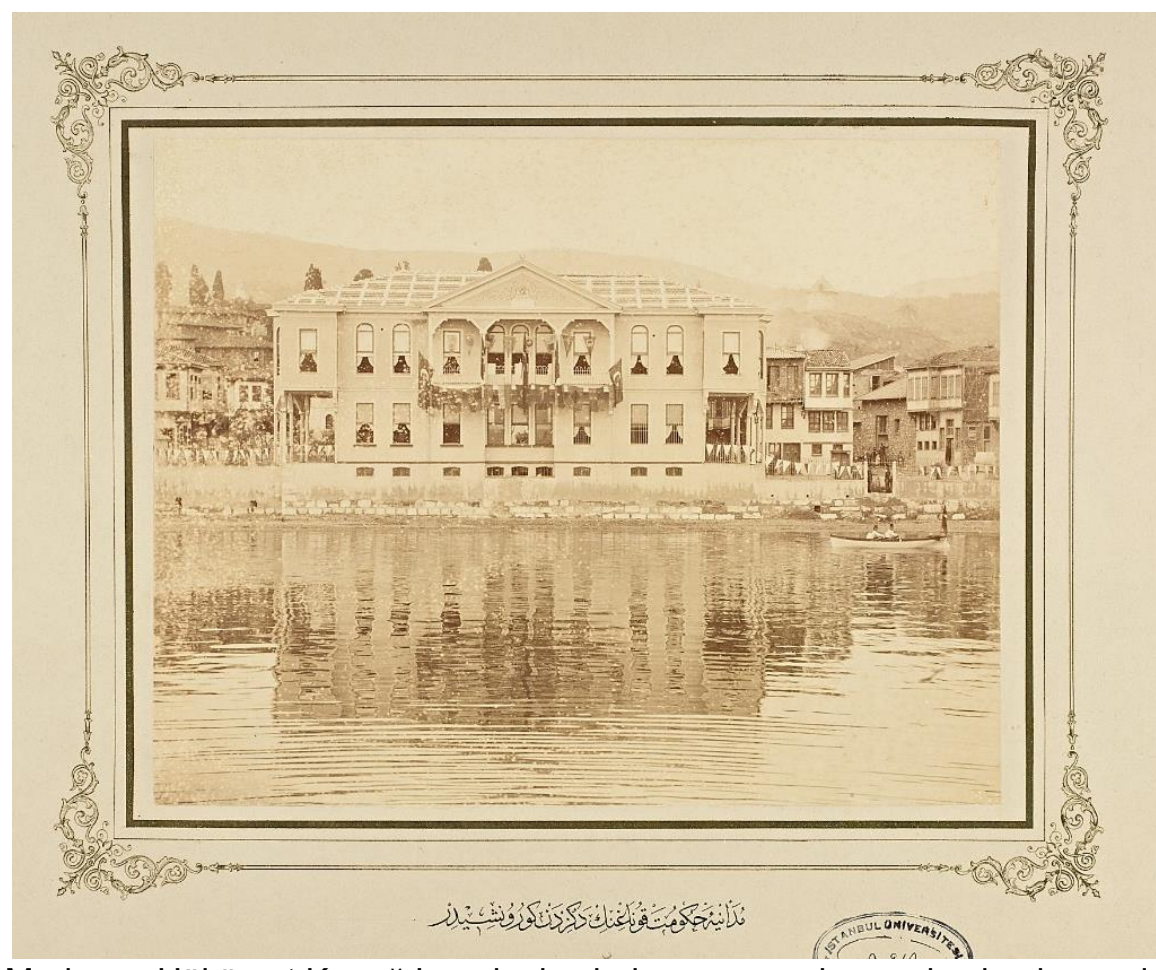

Foto 2. Mudanya Hükümet Konağı'nın denize bakan yan cephe merkezine konumlandırılan balkon tasarımı (i..Ü. Nadir Eserler Kütüphanesi, 90869/0003) 


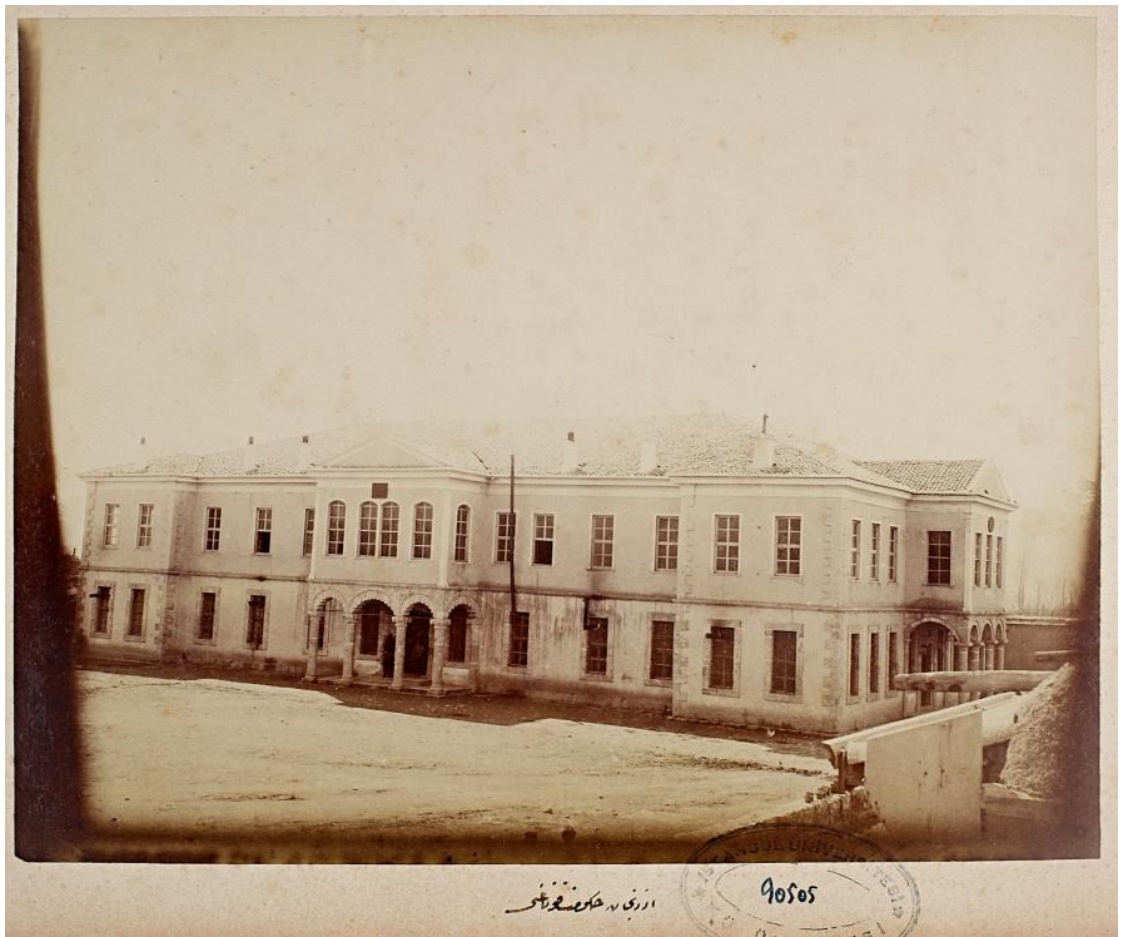

Foto 3. Erzincan Hükümet Konağı cephe merkezlerine yerleştirilen cumbalı çıkıntılar (İ.Ü. Nadir Eserler Kütüphanesi, 90505/0003)

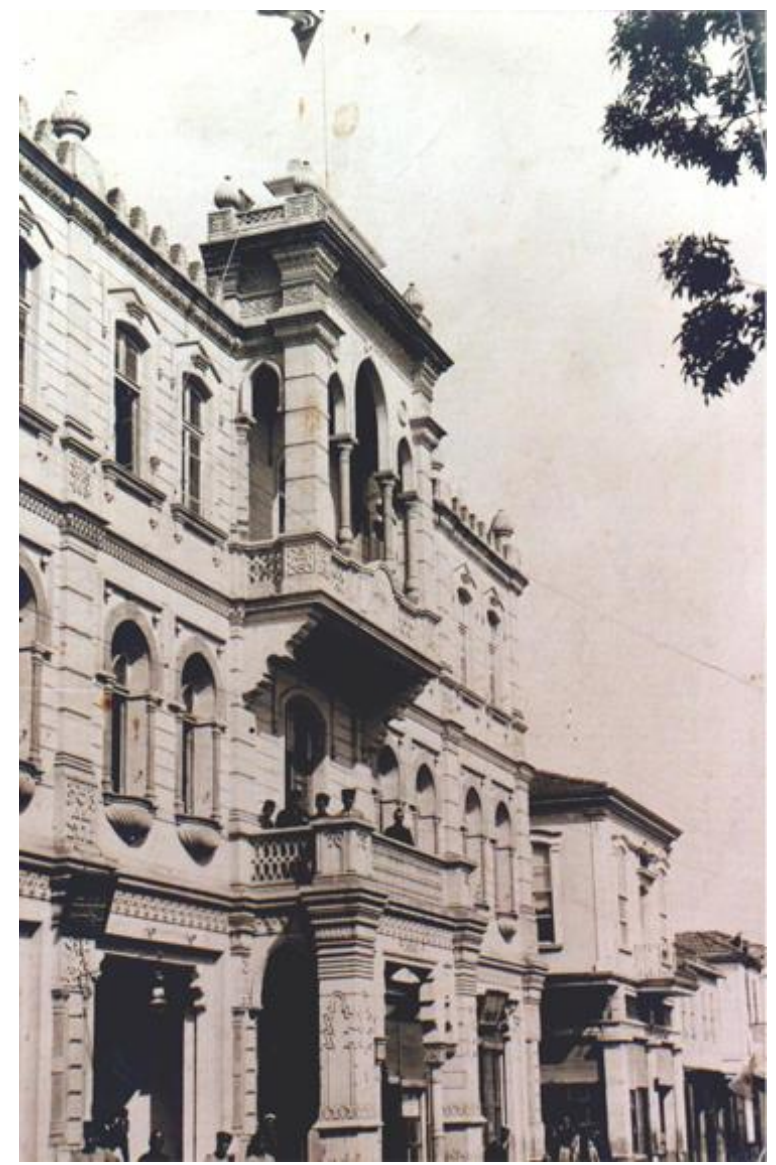

Foto 4. Samsun Belediye Dairesi'nin ana cephesine yerleştirilen balkonlar (Samsun Büyükşehir Belediyesi Arşivi) 


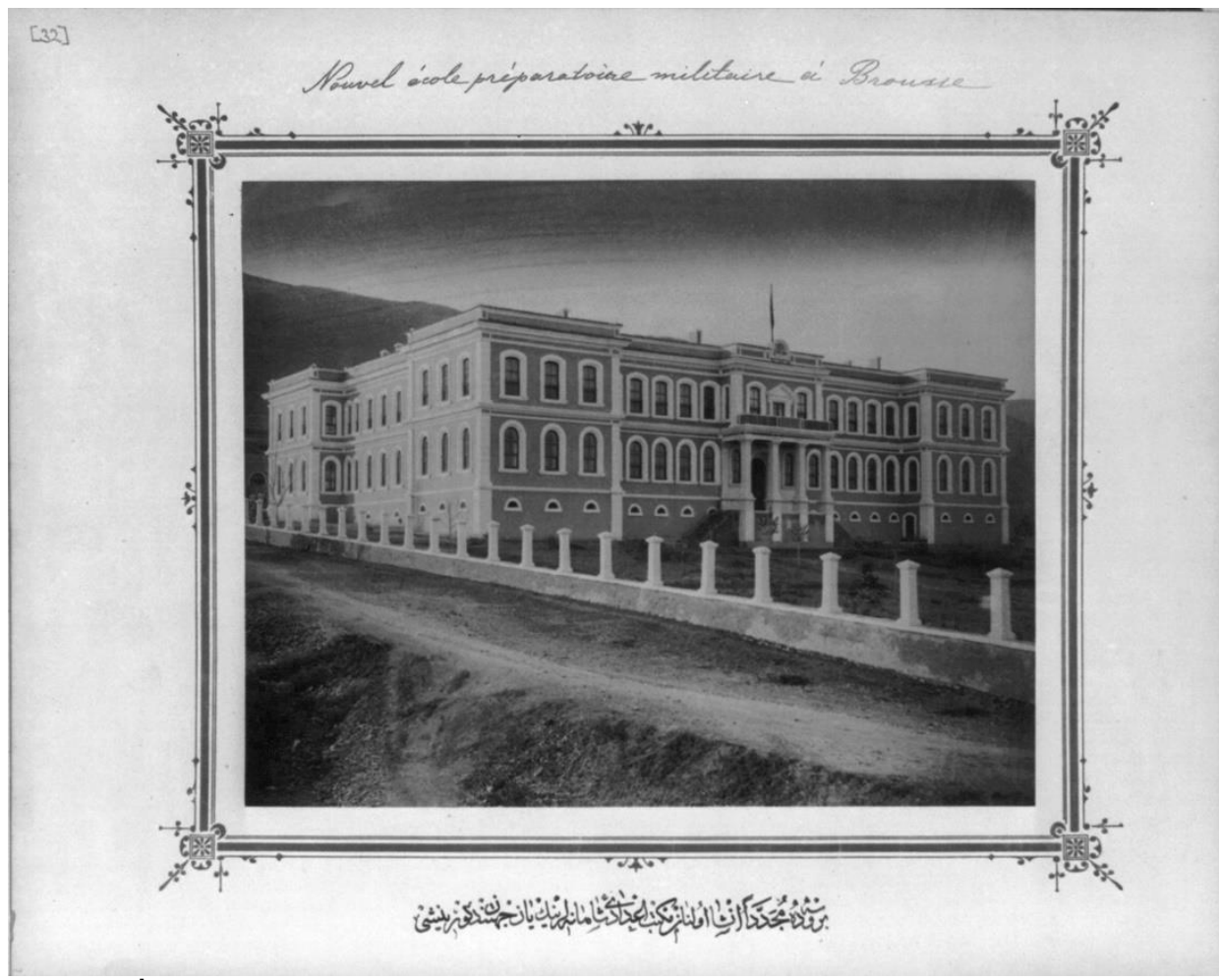

Foto 5. Bursa İdadi Mektebi ana cephe tasarımı ve balkon kullanımı (School Bursa Mekteb-i İdadi-yi)

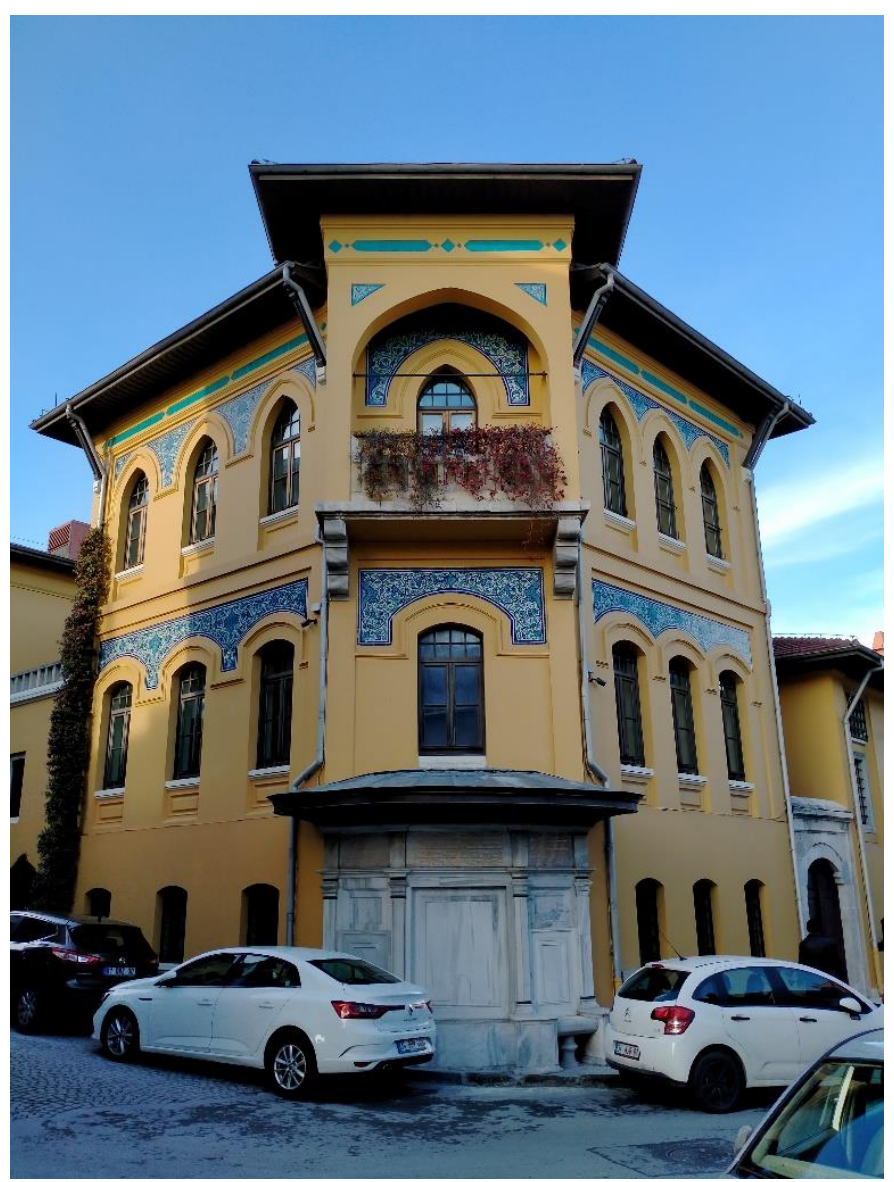

Foto 6. Sultanahmet Tevkifhanesi köşe kütle cephesine konumlandırılan balkon tasarımı (Oğuzhan Ürgen, 2021) 


\section{Geç Dönem Osmanlı Merasimleri ve Toplumsal Hareketlerde Balkonun Kullanımı}

Balkonlar, halka sesleniş mekânı olarak Avrupa siyasi tarihinde önemli bir konuma sahiptir. Özellikle 20. yüzyıl Avrupa liderlerinin balkonları halka sesleniş mekânları olarak tercih ettikleri, meydan-balkon-hitabet ekseninde iktidar ile mekân ilişkisini güçlendirdikleri söylenebilir. 1917'de Lenin'in St. Petersburg'daki evinin balkonundan yaptığı konuşma, 1945'te İngiltere Başbakanı Winston Churchill'in Buckingham Sarayı'nın balkonundan halka seslenişi ve Benito Mussolini'nin 1935'te Palazzo Venezia'nın balkonundan yaptığı meşhur nutuk Avrupa siyasi tarihindeki balkon konuşmalarına örnek gösterilebilir (Bilge, 2015, s.94). Balkonların toplumsal olaylarda ve toplantılarda halka seslenme alanı olarak kullanımı Avrupa toplumu için önemli bir yere sahip olsa da Osmanlı toplumunda balkondan halka seslenme, özellikle sultan veya bir devlet adamı tarafından hiçbir zaman gerçekleşmemiştir. Bununla birlikte Birinci Dünya Savaşı'nın İmparatorluğu yıkıma götürdüğü yıllarda, Yunanistan'ın Batı Anadolu kıyılarına çıkarma yapmasını protesto etmek amacıyla başta Halide Edip Adıvar olmak üzere bir kısım aydın, yönetici ve Wilson Prensipleri Cemiyeti, Karakol Cemiyeti, Türk Ocağı ve Asri Kadınlar Cemiyeti gibi sivil toplum kuruluşlarının yaptığı Sultanahmet, Fatih ve Kadıköy mitingleri, İstanbul halkı tarafından büyük bir ilgiyle karşılanmış, meydanlar binlerce (tahminen 50-70.000) vatandaş ile dolmuştur (Sakaoğlu, 1994a, s.271; Sakaoğlu, 1994b, s.343). Fatih ve Kadıköy mitinglerinde ise konuşmacıların belediye binasının balkonunu kullandıkları görülmektedir. Söz konusu mitinglerde fotoğraf ve kamera teknolojilerinin de kullanılması, bu tarihi olayların ve bu çalışma kapsamında balkonun kullanılmasının kayda alınması bağlamında oldukça kıymetlidir (Foto 7).

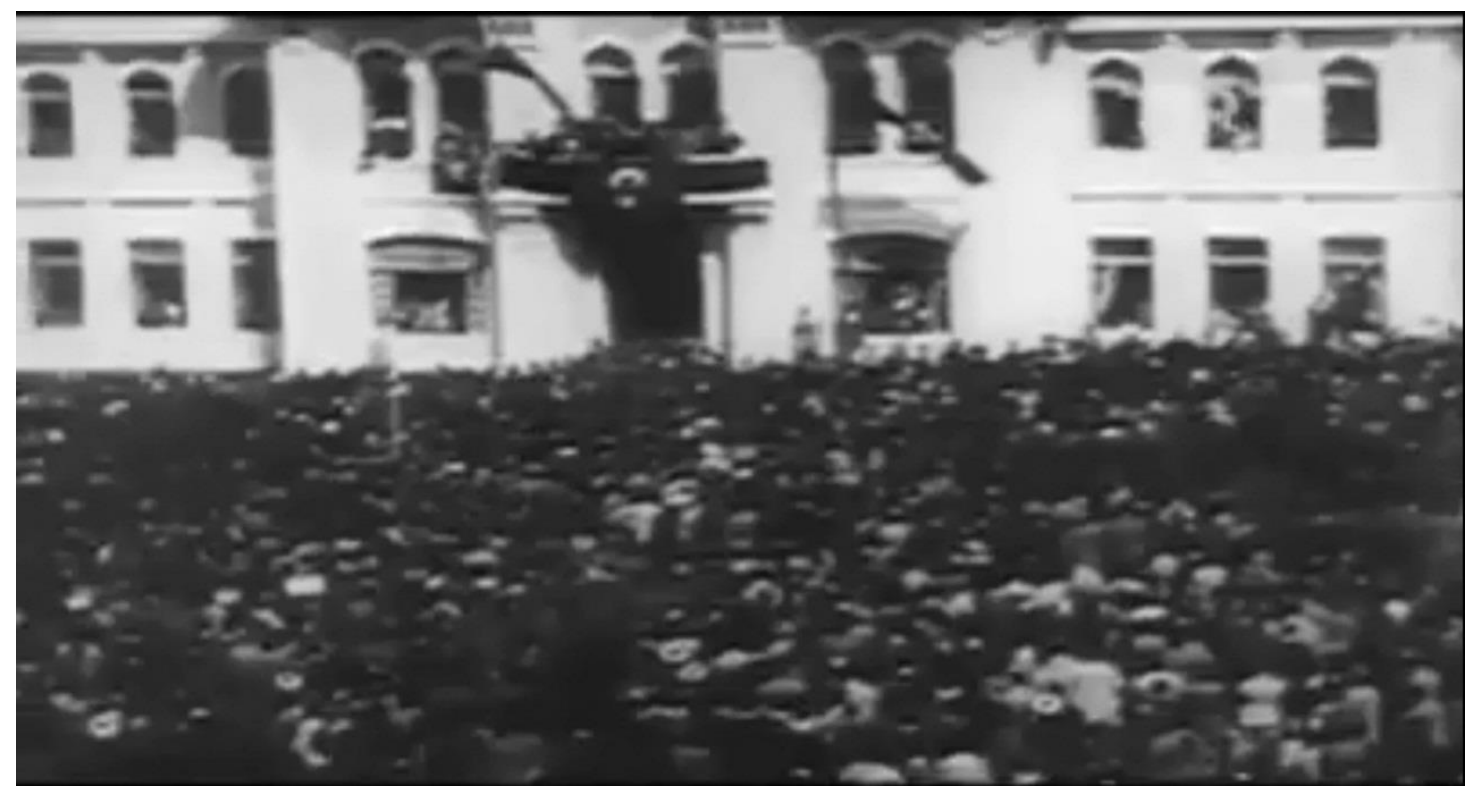

Foto 7. 19 Mayıs 1919 tarihli Fatih Mitingi ve Fatih Belediye Binası balkonundan halka sesleniş konuşmaları (https://www.youtube.com/watch?v=iUR0ap9AcLU, 02.11.2021, 21:45)

Toplumsal hareket bağlamında balkon konuşmalarına bir örnek de Şam'dan verilebilir. 8 Mart 1920 tarihinde Malik Faysal'ın Arap milliyetçilerle beraber Fransız Mandası'na karşı bağımsızlığını ilan ettiği mekânın Şam Belediye dairesinin balkonu olduğu görülmektedir (Weber, 2009, s.22). 1892'de inşa edilen Şam Belediye dairesi ise 1958 yılında yıkılmıştır (Kolay, 2018, s.390) (Foto 8). 


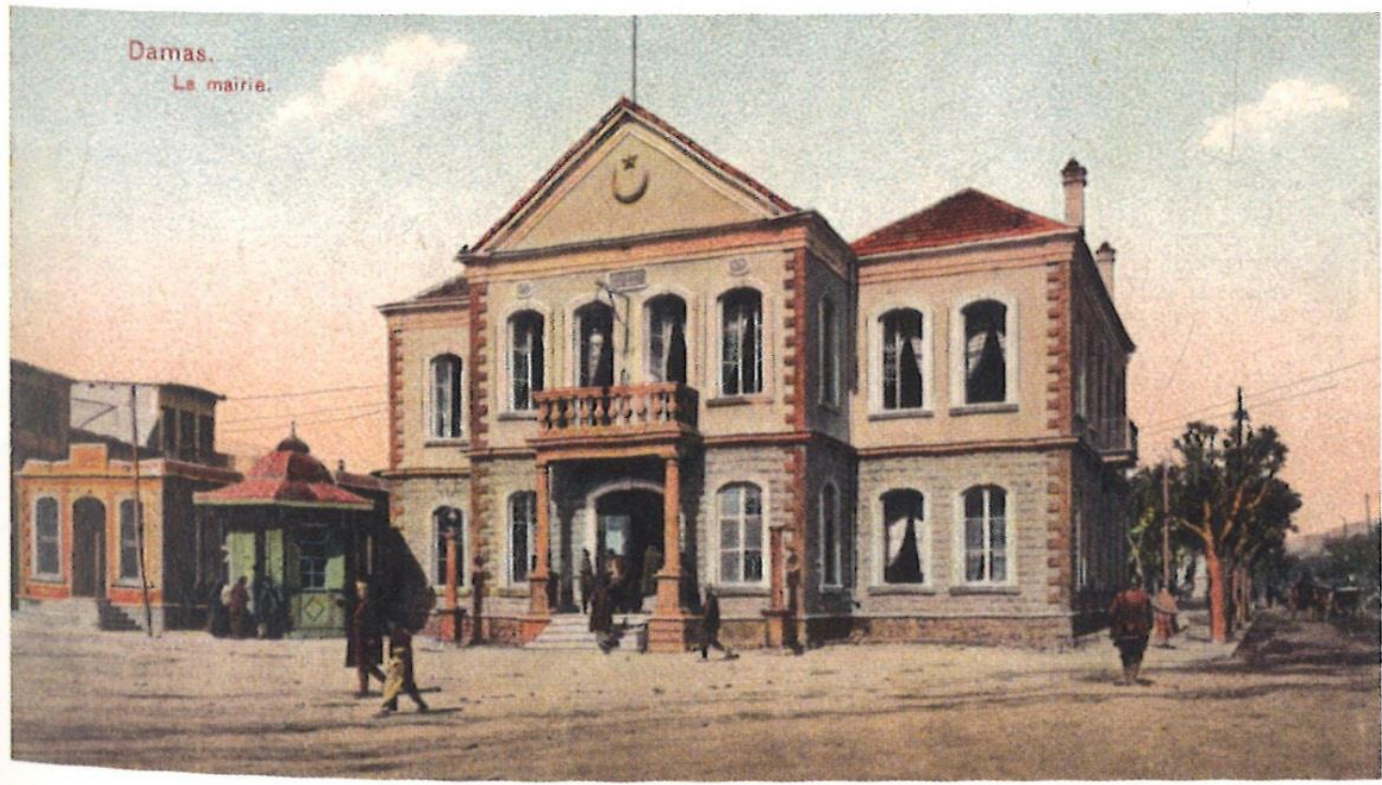

Foto 8. Şam Belediye Binasını gösteren bir kartpostal (Weber, 2009, s.21)

19. ve erken 20. yüzyıl Osmanlı siyaset tarihinde halka sesleniş amaçlı toplumsal hareket tabanının henüz mevcut olmaması, başta padişah olmak üzere üst düzey bürokratların halkla doğrudan ilişkiler kurmak yerine Cuma selamlığı gibi geleneksel usul ve teamülleri devam ettirmeleri kamusal alanın tam manası ile politik bir rekabet alanı olmasının önüne geçmiştir. Bununla birlikte hükümet konağı merkezli kamu sitelerinin meydana getirilişi ve yapıların sahip oldukları biçimsel özellikler doğrudan iktidara gönderme yapmakta, sultan ve çevresi yapılar üzerinden temsilini kent ölçeğinde sürdürmektedir. Söz konusu iktidar imgesi sürecinin en keskin dışavurumu şüphesiz resmi açılışlar, bayramlar ve devlet için özel günlerde açığa çıkmaktadır. Henüz tamamlanmış bir kamu yapısının -ki gerek işlevi gerekse kütlesel özellikleri farketmeksizin- resm-i küşâdı (resmi açılışı) bölge ileri gelenleri tarafından şaşaalı bir tören ile gerçekleştirilmekte, askerler, öğrenciler, esnaf ve tebaadan pek çok katılımcı büyük bir ciddiyet ile yeni yapının önünde poz vermektedir. Yapı detaylarına baktığımızda ise pencere, kapı ve balkon gibi açıklıkların bayraklar, flamalar, çelenkler ve çiçeklerle süslendiğini takip edebilmekteyiz. Bölge için çok önemli bir gün olan açılış merasiminin kimi ulusal gazete ve dergiler de fotoğraflanarak haber haline getirildiğini sıklıkla görürüz. Servet-i Fünun, İrtika, Malumat gibi dönem gazete ve dergilerine kabaca göz atıldığında sadece Osmanlı coğrafyası için değil, fakat yurtdışından da çeşitli yapı açılış haberlerinin paylaşıldığını okuyabiliriz. Burada, balkon tasarımına sahip kamu eserlerinde balkon detaylarının abartılı biçimde süslendiği, kimi zaman idarecilerin, askerlerin ve öğrencilerin balkon üzerinde poz verdiklerine şahit oluruz. Servet-i Fünun'da fotoğrafı paylaşılan Edirne daire-i askeriyesi'nin resm-i küşadı yukarıda sıraladığımız usul ile yeni binanın hemen önünde poz veren bir grup vatandaş ile gerçekleştirilmekte ve özellikle balkon açıklığı bayraklar ile süslenmektedir (Foto 9). Törenlerde balkonun bayrak ve flamalarla süslenmesine örnek olarak Tokat Belediye Binası önündeki töreni kayda alan bir fotoğraf (Foto 10), Konya'da Hilal-i Ahmer binasında figürlerin yer almadığı ama balkonun aynı derecede süslendiğini gösteren bir fotoğraf (Foto 11), Kirmasti (Mustafakemalpaşa) Rüşdiye Mektebi'nin resm-i küşadını gösteren fotoğraf (Foto 12), İslahiye Hükümet Konağı'nın açılışında ana cephenin bayraklarla süslendiği ve balkona "padişahım çok yaşa" pankartının asıldığını gösteren 1903 tarihli fotoğraf (Foto 13), yine Servet-i Fünun'un 16 Ekim 1901 tarihli kapağını süsleyen Malkara Belediye Dairesi'nin açılış törenini gösteren bir fotoğraf (Foto 14) ile Adana Hükümet Konağı'nın açılış törenini sunan 10 Ekim 1901 tarihli fotoğraf (Foto 15) balkonun resmi törenlerdeki statüsünü sunması bağlamında 
dikkat çekici örnekler olarak sıralanabilir. İstanbul Üniversitesi Nadir Eserler Kütüphanesi kataloğunda yer alan tarihsiz bir fotoğraf, hemen altındaki "İmir hükümet konağı ile bahçesinin yevmi velâdet-i bâhir-ül mes'adeti hümayun'da alınan resmidir" notuyla padişah veya bir hanedan üyesinin doğum günü kutlamaları sırasında İzmir Hükümet Konağı ve bahçesinin durumunu göstermektedir. Söz konusu fotoğrafta hükümet konağının ana cephe merkezinde yer alan balkon ve balkonu taşıyan sütunlar, bayrak, çiçek ve çelenkler ile süslenmiş, memurlar ise balkon üstünden poz vermişlerdir (Foto 16).

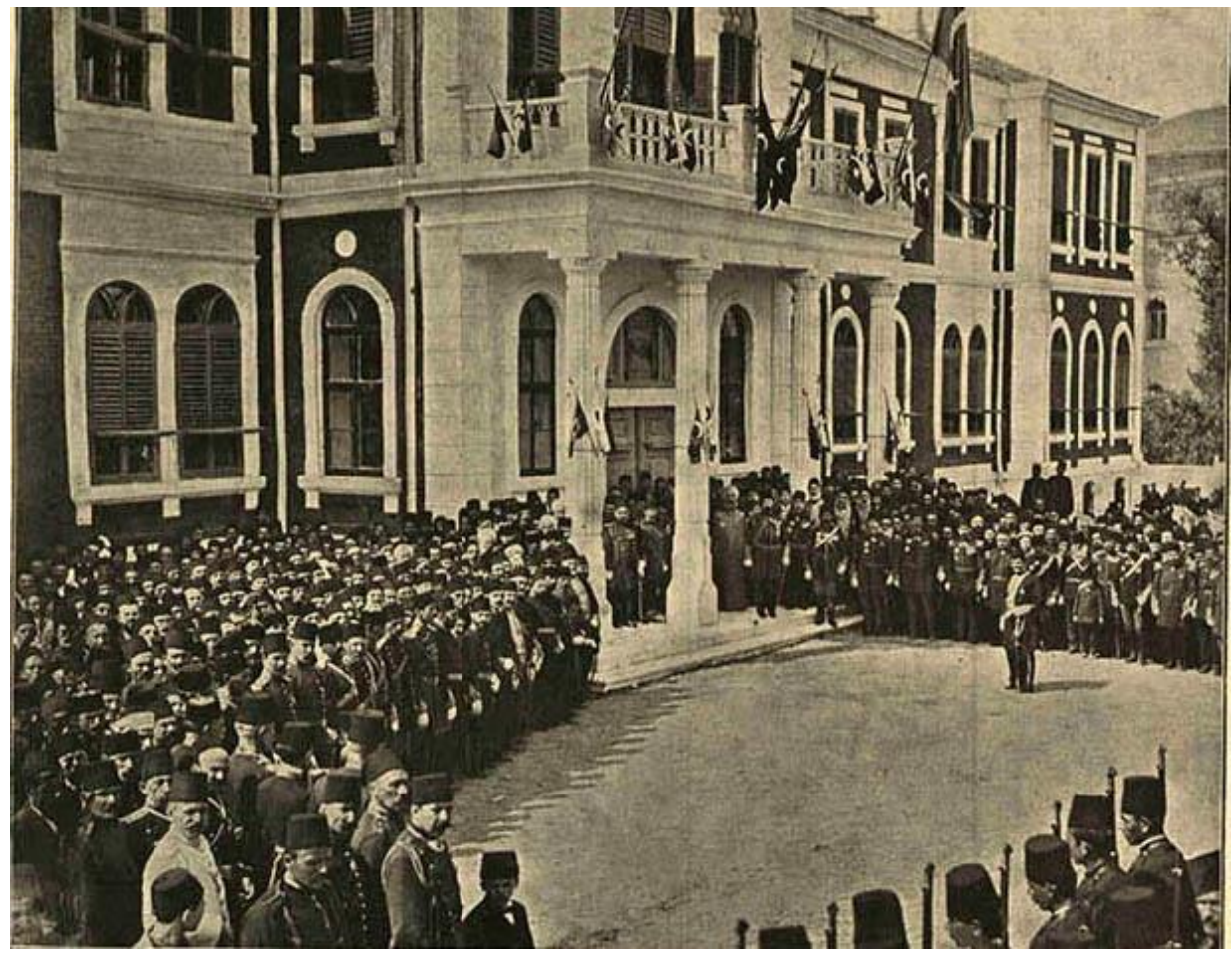

Foto 9. Edirne Daire-i Askeriyenin resm-i küşadı (Servet-i Fünun, 449, 1899).

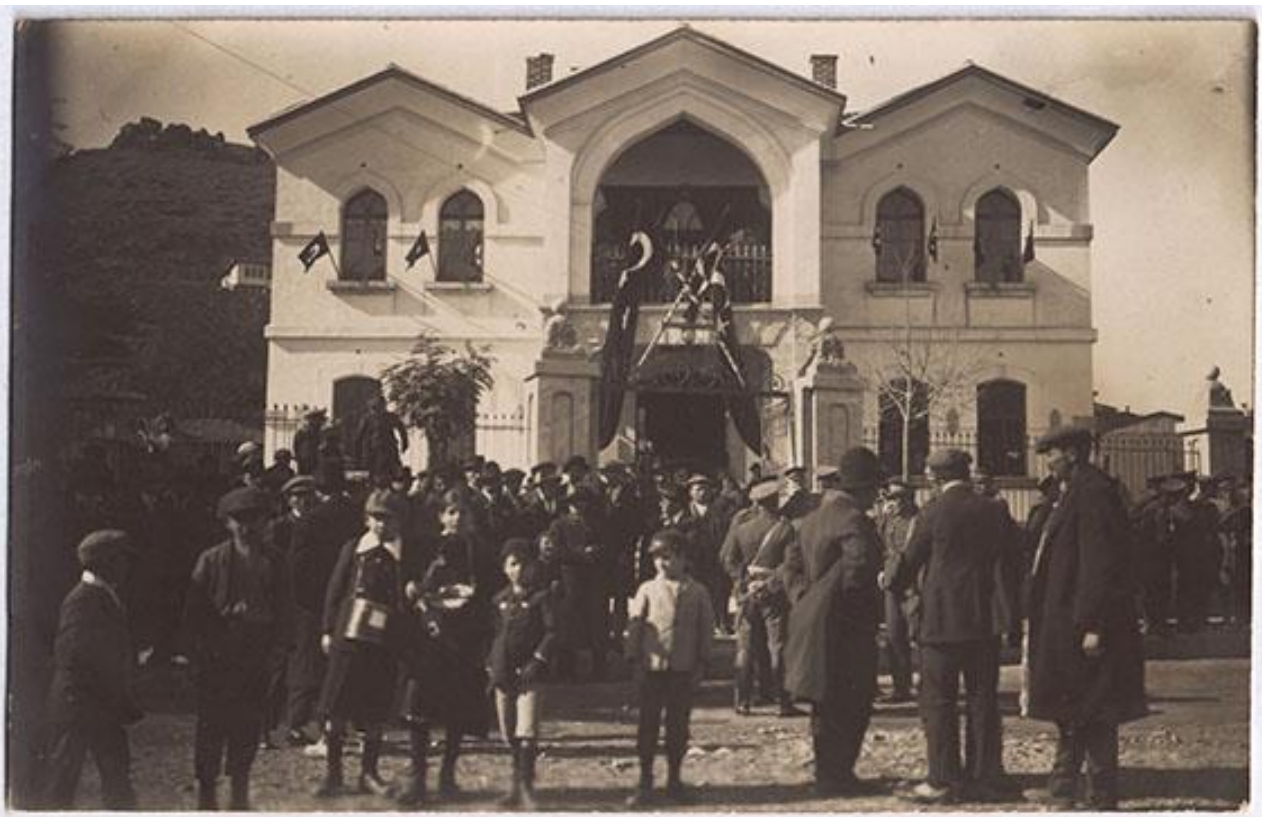

Foto 10. Tokat Belediye Dairesi önünde gerçekleşen bir tören ve yapının balkon süsleme detayı (Atatürk Kitaplığı Fotoğraf Arşivi, Krt_016549) 


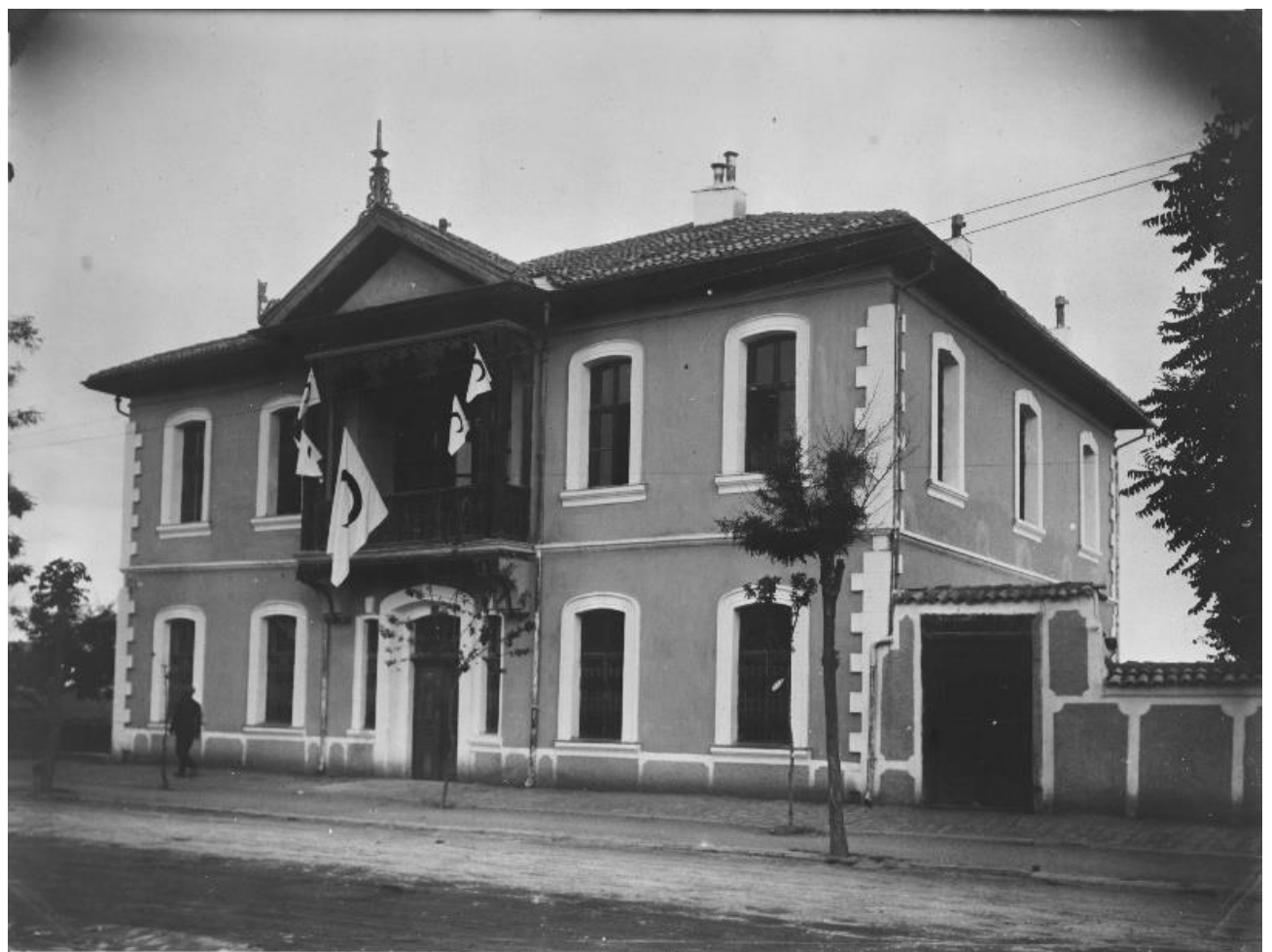

Foto 11. Konya Hilal-i Ahmer Binası ve balkon detayı (Karpuz, 1998, s.158)

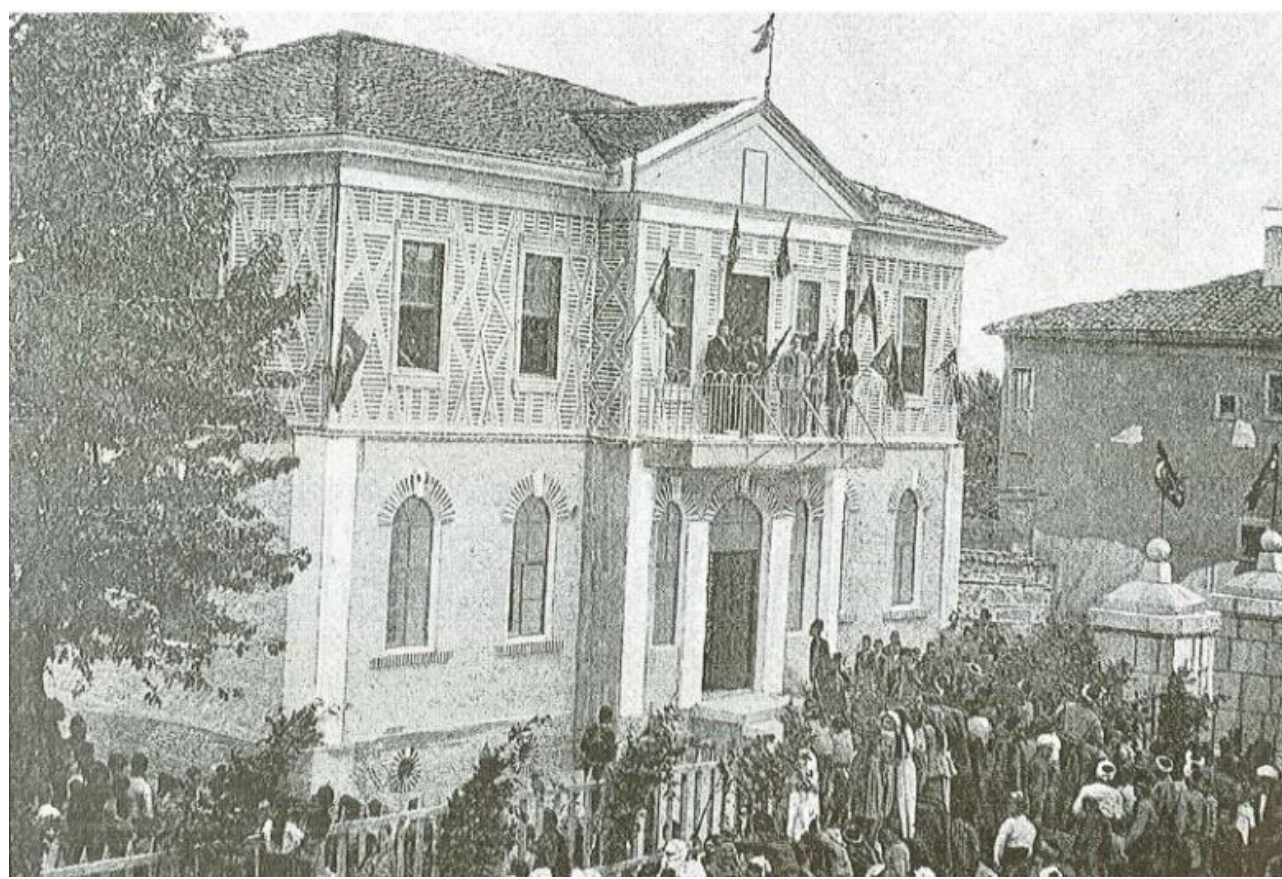

Foto 12. Kirmasti (Mustafakemalpaşa) Rüşdiye Mektebinin açılış töreni (Yılmaz, 2007, s.127) 


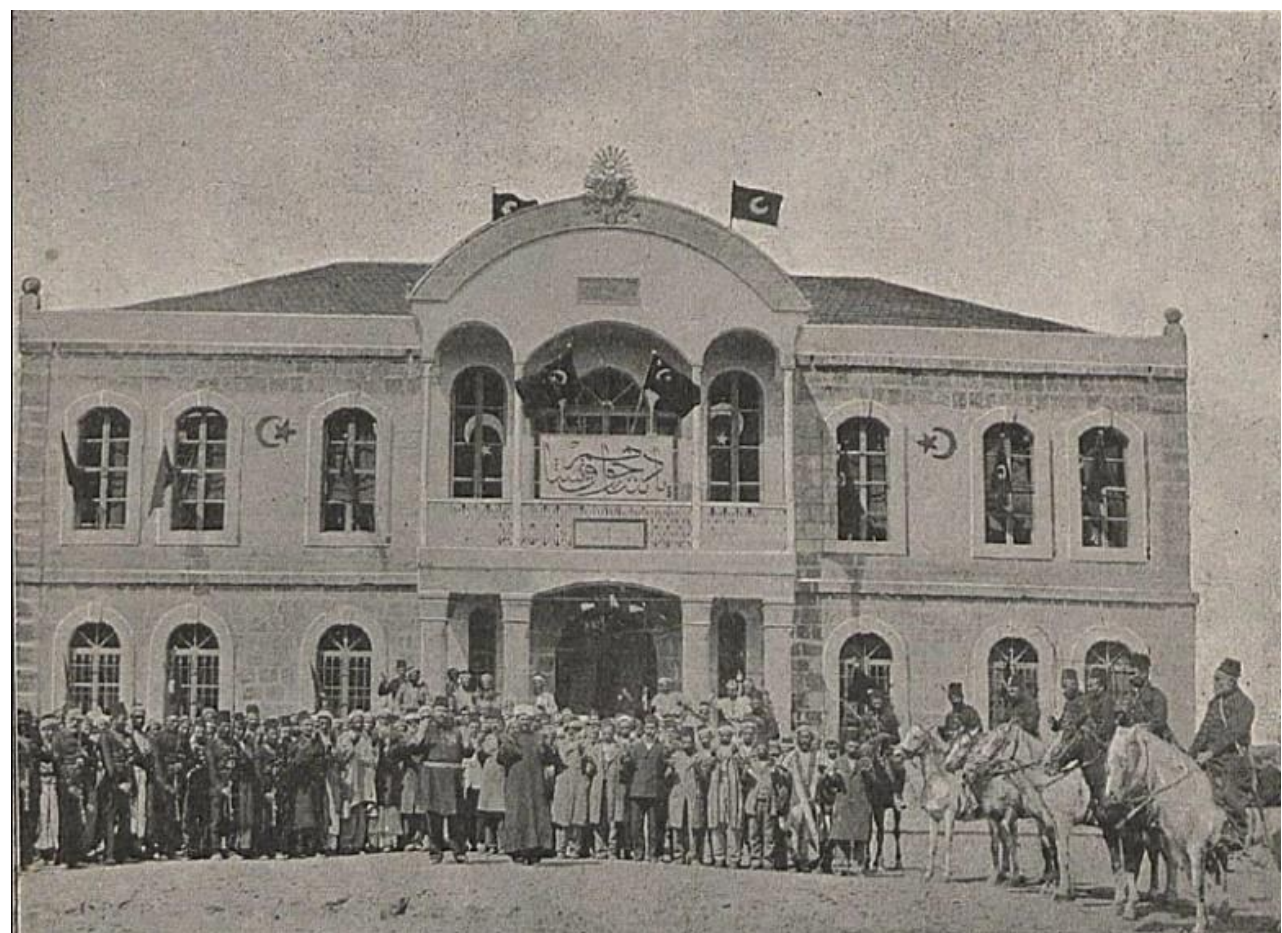

Foto 13. 1903 tarihli İslâhiye Hükümet Konağı açılış töreni ve balkon detayı (Umar, 2017, s.76)

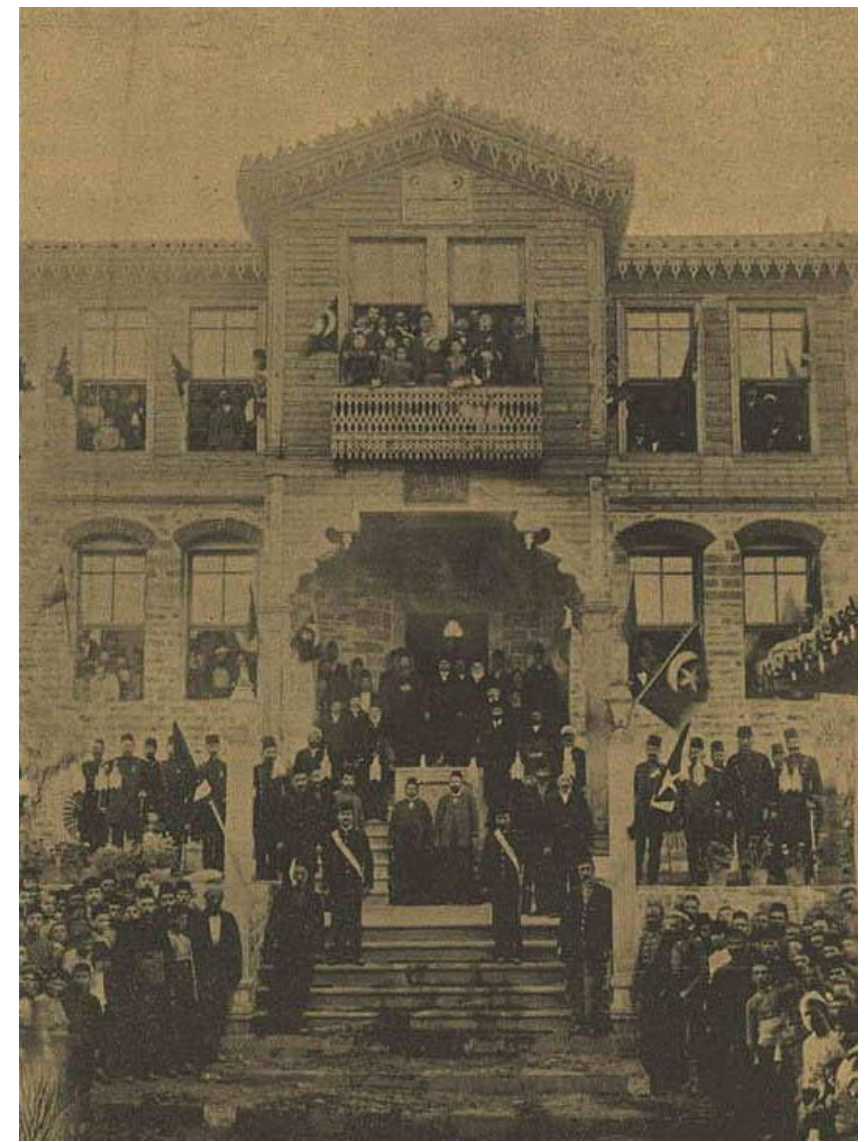

Foto 14. Malkara Belediye Dairesi'nin açılış töreni ve balkonun törendeki kullanımı (Servet-i Fünun, 553, 1901) 


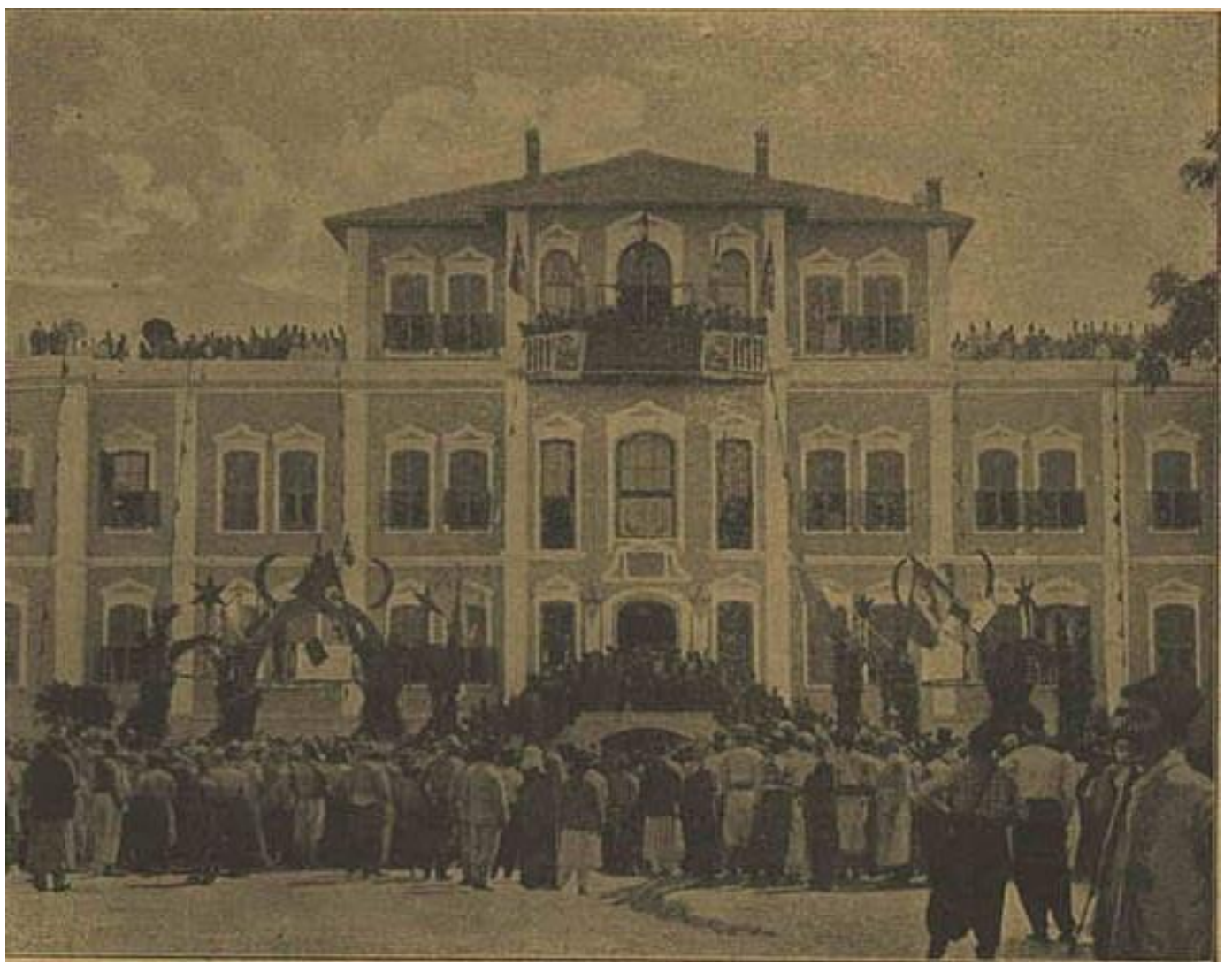

Foto 15. Adana Hükümet Konağı ve cephe merkezindeki balkon tasarımı (Servet-i Fünun, 552, 10 Ekim 1901)

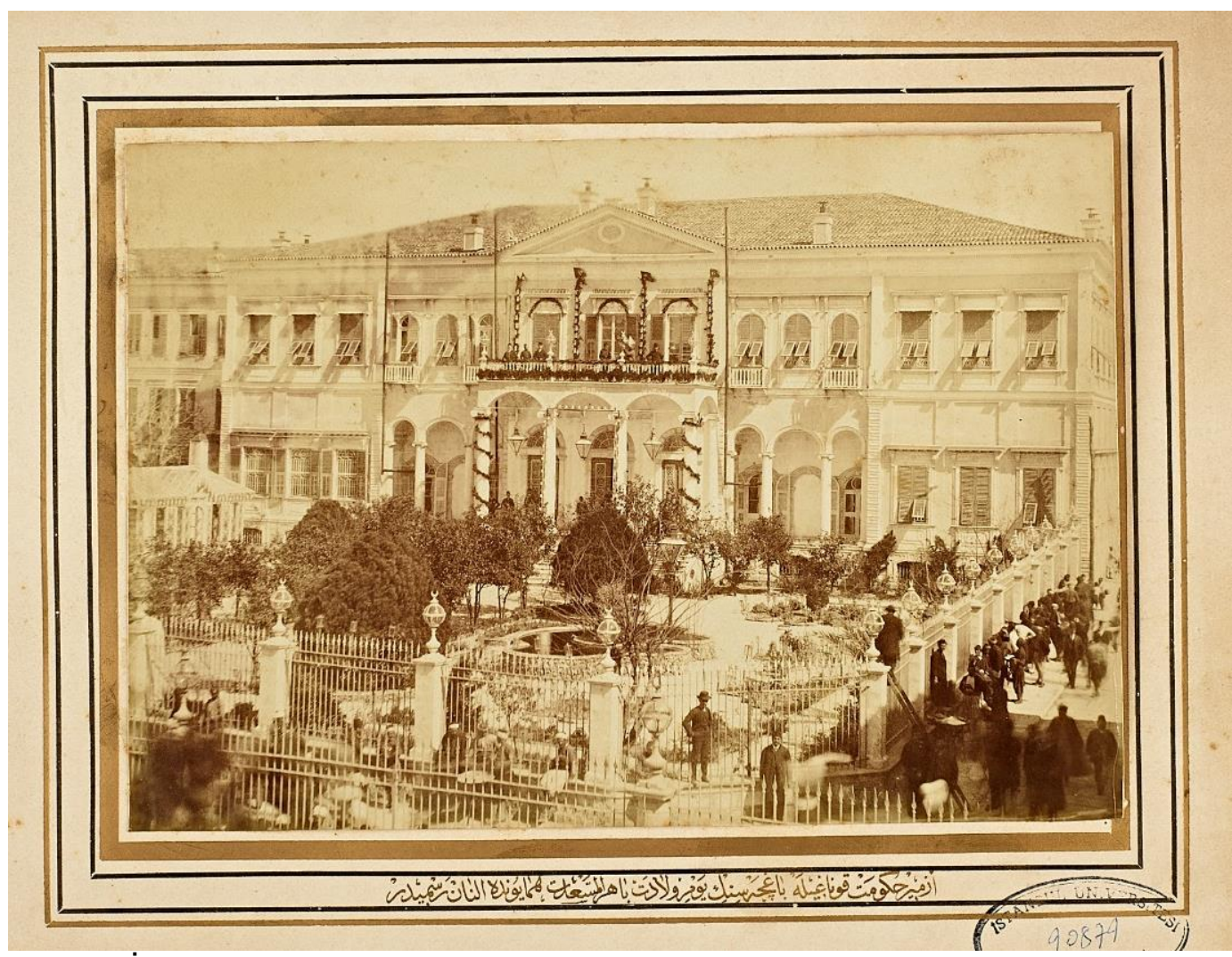

Foto 16. İzmir Hükümet Konağı'nın balkon tasarımı ve padişahın doğum günü kutlamalar sırasında kullanımı (i..Ü. Nadir Eserler Kütüphanesi, 90879/0001) 


\section{Sonuç: Bir İktidar İmgesi Bağlamında Balkon}

19. yüzyılda tüm dünya ile eş zamanlı olarak Osmanlı coğrafyasında da özellikle mimari faaliyetler ile yaygınlık kazanan iktidar imgeleri elbette modernitenin getirmiş olduğu bir iktidar refleksi değildir. Tahta çıkış seremonileri, hil'at giydirme, sikke basma, hutbe okutma ve cülus gibi modern öncesi saltanat uygulamalarının da bir iktidar imgesi olarak okunması mümkündür (Koca, 1995, s.73-74). Necipoğlu, Topkapı Sarayı'nın mimari bileşenlerinin Osmanlı imparatorluk ideolojisine ve sultanın iktidarı imgesine katkı sağladığını vurgulamakta, Fatih Sultan Mehmet döneminde başlayan teşrifatın sonraki dönemlerde de devamlılık sağladığı, sultanın "ulaşılamaz/erişilemez" imgesinin güçlendirildiğini dile getirmektedir (Necipoğlu, 2014, s.19-20). "Görsel ideoloji" olarak adlandırılan, padişahın kendi iktidarını farklı aygıtlarla tebaasına aktarma sürecinin 18. yüzyılda değişime uğradığı, II. Mahmud dönemiyle birlikte sultanın özellikle yeniçerilere karşı giriştiği mücadele sonrası "görsel ideolojisini" sunmak adına yaptırdığı mimari eserlerden resmi dairelere astırdığı portrelere kadar hemen her enstrümanı kullandığı görülür (Özlü, 2021, s.201, 219). 19. yüzyıl içinde giderek belirginleşen ve sultanın iktidar erki ve temsilini sembolize eden somut ögelere, özellikle II. Abdülhamid döneminde devlet politikası haline gelen sosyal yardımlaşma faaliyetlerinin de iktidarın meşruiyetini güçlendirmesi adına önemli katkılar sağladığı söylenebilir (Özbek, 2020, s.332). Bu bağlamda 19. yüzyılın ikinci yarısı içinde kurulan Darüşşafaka Cemiyeti (1863), Hilal-i Ahmer Cemiyeti (Türk Kızılay, 1868), pek çok kentte açılan Gureba hastaneleri ve II. Abdülhamid'in bizzat ilgilendiği Hamidiye Etfal Hastanesi (1899), Osmanlı İmparatorluğu'nun sosyal devlet politikasının önde gelen temsilleri sayılabilirler. Aynı zamanda Tanzimat'ın ilanından itibaren çıkartılmaya başlanan ve kısmen uygulamaya sokulan dilenciler, evsizler ve serserilerle ilgili nizamnameler de iktidarın kentin gündelik yaşamı içindeki müdahale ve güç gösterisini sembolize etmektedir.

Tanzimat'ın ilanından hemen sonra, fermanı tüm kentli ile kalıcı olarak paylaşma kaygısıyla gelişen anıt inşa etme fikri, 19. yüzyılda iktidar imgesi yaratımının ilk göstergelerinden sayılabilir. Gaspare Fossati'nin 1840 yılında tasarladığı Hatt-ı Şerif Anıtı ile Artin Bilezikçi'nin 1855 yılında tasarladığı Tanzimat Abidesi projesi, Vakanüvis Ahmed Lütfi'nin belirttiği üzere halkın olumsuz tepkisi göz önüne alınarak rafa kaldırımıştır (Avcı ve Avcı, 2017, s.26-29; Kreiser, 1997, s.103-104). Bundan sonra ancak II. Meşrutiyet döneminde hız kazanan anıt inşası, Cumhuriyet ile birlikte figüratif bir kimlik kazanacaktır. İktidar temsilini güçlü bir şekilde sunan toplumsal faaliyetlerin II. Abdülhamid döneminde yoğunlaştığı bilinmektedir.

Bu dönemde Cuma selamlıkları, tahta çıkış yıldönümleri -ki özellikle II. Abdülhamid'in tahta çıkışının 25. yıl dönümü bu anlamda oldukça fazla detay içermektedir-, bayramlar, yabancı devlet adamlarının ziyaretleri ve resmi yapı açılışları iktidar imgesinin en güçlü göstergeleri olarak okunabilir. Tahta çıkış törenlerinin kamuoyundaki etkisi o kadar geniştir ki vatandaşların şahsi konaklarını bir kamu yapısı gibi süsledikleri ve gazete sayfalarında haberleştirildikleri görülür (Karateke, 2017, s.60). II. Abdülhamid'in ülkenin her köşesinden istediği fotoğraflar ile zengin bir fotoğraf koleksiyonu yaratması, koleksiyonun belli bölümlerini propaganda amacı ile yerel ve ulusal gazetelere dağıtması ve hatta farklı ülke kurumlarına bağışlaması da dönemin fotoğraf teknolojisinin II. Abdülhamid tarafından ne derece iktidar imgesi olarak kullanıldığını göstermektedir (Güntan, 2007, s.14). Söz konusu fotoğraflarda konuya dâhil edilen resmi yapı açılışlarının gerek yapının süslenmesi gerekse bölgedeki tüm memur, asker ve öğrencilerin toplanıp yeni yapı önünde poz vermesiyle modernleşen devletin görsel temsiline katkı sağladığı düşünülebilir. Burada, balkonların sahip olduğu bayrak, arma, flama, çelenk vb. unsurlar ile ayrıca hareketlendirilerek ve kimi zaman da memurların balkonda poz vermesiyle fotoğrafın sahip olduğu iktidar imgesine ayrıca katkı sağladığı 
düşünülebilir. Yukarıda da değinildiği üzere söz konusu balkonların gündelik kent yaşamında da üzerinde sahip olduğu kitabe, arma ve tuğra gibi simgesel ögelerle hâlihazırda yapının iktidar imgesine katkı sağladığı görülmektedir. Özellikle arma-i Osmanî'nin kamu yapılarının cephe tasarımlarında yaygınlık kazanması (Kırıkcı ve Urfalıoğlu, 2015, s.53), yapıların devlet temsili hüviyetini açığa çıkarmaktadır. Açılış ve bayram gibi toplumu ilgilendiren merasimlerde de ayrıca bu alanın süslenerek vurgulanması, balkonun iktidarı temsili yönündeki değerlendirmemizi güçlendirmektedir. II. Abdülhamid döneminde yoğunluk kazanan kamu eserlerindeki balkon tasarımının II. Meşrutiyet döneminde de hız kesmeden projelere dahil edildiği görülür. Bu dönemde de tuğra, kitabe ve arma-i Osmani bir iktidar imgesi olarak balkonlarda yerini almıştır. II. Meşrutiyet ile birlikte artan toplumsal hareketler, dönemin askeri ve siyasi gelişmelerine paralel olarak Osmanlı toplumunda daha sık yer edinmeye başlamıştır. Bu bağlamda 1919'da yaşanan ve görsel kayda geçen mitingler, erken 20. yüzyıl Türkiye'sinin değişen toplum dinamiklerini sergilemekte, vurgulanan olay ve mekanların başında ise balkon konuşmalarının gelmesi 19. yüzyılda balkona yüklenen iktidar imgesinin dönüşerek canlı tutulduğunu göstermektedir. Bu süreç günümüz siyasetinde yer edinmiş olan "balkon konuşması" ile devam etmektedir.

Çalışmamız, balkonun 19. yüzyıl Osmanlı mimarisinde bir iktidar temsili olarak okunabilirliğini göstermekle birlikte, kamu yapılarının sahip olduğu balkonların tek başına bu temsiliyeti üstlenmediğini, kütlesel özellikleri, süsleme detayları ve tören teşrifatıyla bir bütünlük arz ederek iktidar imgesine katkı sağladığını göstermektedir.

\section{Kaynaklar}

Arseven, C. E. (2017). Osmanlı Dönemi Mimarlık Sözlüğü Istılâhât-ı Mi’mâriyye. (çev. Şeyda Alpay). (1. Baskı). İstanbul: Kaknüs Yayınları

Atatürk Kitaplığı, Katalog No: Krt_016549.

Avcı, Y. ve Avcı S. (2017). Osmanlı İmparatorluğu'nda Siyasi Meşruiyet ve Propaganda Aracı Olarak Anıtın İcadı (1840-1917). Kebikeç, (43), 23-46.

Bilge, R. (2016). Siyasal İletişimde Mekan Üzerinden Söylem Üretiminin Önemi: Balkon ve Meydanlarda Söylem Üretimi. (Yayımlanmamış yüksek lisans tezi) İstanbul Üniversitesi Sosyal Bilimler Enstitüsü, İstanbul.

Deringil, S. (1999). The Well-Protectred Domains: Ideology and the Legitimation of Power in the Ottoman Empire 1876-1909. (1. Baskı). London and New York: I. B. Tauris. Erzincan Hükümet Konağı. Türkiye, Erzincan, [Tarihsiz], [Fotoğraf] İstanbul Üniversitesi Nadir Eserler Kütüphanesi, 90505/0003. http://nek.istanbul.edu.tr:4444/ekos/FOTOGRAF/90505---0003.jpg

Güntan, Ç. (2007). II. Abdülhamit Döneminde İmparatorluk İmajının Kamu Yapıları Aracılığı ile Osmanlı Kentine Yansıtılması. (Yayımlanmamış yüksek lisans tezi) Yıldız Teknik Üniversitesi Fen Bilimleri Enstitüsü, İstanbul.

Hasol, D. (2010). Ansiklopedik Mimarlık Sözlüğü. (11. Baskı). İstanbul: Yapı-Endüstri Merkezi Yayınları.

Hobsbawm, E. (2013). Giriş: Gelenekleri İcat Etmek. Geleneğin İcadı içinde (1-18). Hobsbawm, E. ve Ranger T. (Der.), İstanbul: Agora Kitaplığı. 
İzmir Hükümet Konağı. Türkiye İzmir, [Tarihsiz], [Fotoğraf] İstanbul Üniversitesi Nadir Eserler Kütüphanesi, 90879/0001. http://nek.istanbul.edu.tr:4444/ekos/FOTOGRAF/90879---0001.jpg

Karateke, H. T. (2017). Padişahım Çok Yaşa! Osmanlı Devleti'nin Son Yüzyılında Merasimler. (1. Baskı). İstanbul: Türkiye İş Bankası Kültür Yayınları.

Karpuz, H. (1998). Fotoğraflarla Geçmişte Konya. (3. Baskı). İstanbul: Konya Büyükşehir Belediyesi Yayınları.

Kırıkcı, E. ve Urfalıoğlu N. (2015). Usage of Ottoman State Emblems in the Architecture of the 19th Century Istanbul. Sigma, 6(1), 43-53.

Koca, S. (1995) Türkiye Selçuklu Sultanı I. İzzettin Keykavus'un Aldığı ve Kullandığı Hakimiyet Sembolleri. Belleten, 59(224), 55-74.

Kolay, E. (2018). Osmanlı Yerel Yönetim Sisteminin Mimari Alana Yansıması: Tanzimat'tan Cumhuriyet'e Belediye Binaları. (Yayımlanmamış doktora tezi) Ankara Üniversitesi Sosyal Bilimler Enstitüsü, Ankara.

Kolay, E. Arşiv Belgeleri Işığında Osmanlı Hapishane Mimarisi. (1. Baskı). Erzurum: Atatürk Üniversitesi Yayınları.

Kreiser, K. (1997). Public Monuments in Turkey and Egypt 1840-1916. Muqarnas, 14, 103-117.

Mudanya Hükümet Konağı. Türkiye Mudanya, [Tarihsiz], [Fotoğraf] İstanbul Üniversitesi Nadir Eserler Kütüphanesi, 90869/0003. http://nek.istanbul.edu.tr:4444/ekos/FOTOGRAF/90869---0003.jpg

Necipoğlu, G. (2014). 15. ve 16. Yüzyılda Topkapı Sarayı; Mimari, Tören ve İktidar (çev. Ruşen Sezer), (2. Baskı), İstanbul: Yapı Kredi Yayınları.

Nişanyan, S. (2004). Sözlerin Soyağacı Çağdaş Türkçenin Etimolojik Sözlüğü. (2. Baskı). İstanbul: Adam Yayınları.

Özbek, N. (2020). Osmanlı İmparatorluğu'nda Sosyal Devlet: Siyaset, İktidar ve Meşruiyet 1876-1914. (7. Baskı). İstanbul: İletişim Yayınları.

Özgen, M. M. (2016). Sultan İkinci Abdülhamid Han Devri Osmanlı Redif Binaları. (1. Baskı). İstanbul: Hamidiye Kitaplığı.

Özlü, N. (2021). II. Mahmud Döneminde İstanbul: Kent, İdeoloji ve Mimari. Mimarlık ve Yaşam Dergisi, 6(1), 199-222.

Sakaoğlu, N. (1994a). Fatih Mitingi. Dünden Bugüne İstanbul Ansiklopedisi içinde (1. Baskı. Cilt 3, 271). İstanbul: Kültür Bakanlığı ve Tarih Vakfı Ortak Yayınları.

Sakaoğlu, N. (1994b). Kadıköy Mitingi. Dünden Bugüne İstanbul Ansiklopedisi içinde (1. Baskı. Cilt 4, 343). İstanbul: Kültür Bakanlığı ve Tarih Vakfı Ortak Yayınları. 
Sarı, N. ve İzgöer, A. Z. (2021). Osmanlı Dönemi Modern Sağlık Yapılarının Planlarından Öğrendiklerimiz. Türk Tıp Etiği, Tıp Hukuku ve Tıp Tarihi Araştırmaları Yıllığı, $(10,11,12,13,14), 69-132$.

School Bursa Mekteb-i İdadi-yi. Turkey Bursa, None. [Between 1880 and 1893] [Photograph] Retrieved from the Library of Congress, https://www.loc.gov/item/2001699032

Servet-i Fünun, 449, 7 Teşrinievvel 1315 R. (19 Ekim 1899 M.)

Servet-i Fünun, 552, 27 Eylül 1317 R. (10 Ekim 1901 M.)

Servet-i Fünun, 553, 3 Teşrinievvel 1317 R. (16 Ekim 1901 M.)

Sözen, M. ve Tanyeli U. (2011). Sanat Kavram ve Terimleri Sözlüğü. (10. Baskı). İstanbul: Remzi Kitabevi.

Şenyurt, O. (2016). İnşa Kuralları, Mimari Algı ve Mekan Kullanımı Bağlamında Osmanlı Toplumunda "Cumba"/"Şahnişin. Mimarlık ve Yaşam Dergisi, 1(1) 87-103.

Şenyurt, O. (2018). Osmanlı Mimarisinde Mekân ve Yaşam Zamanın Mekânları Mekânın Zamanları. (1. Baskı). İstanbul: Doğu Kitabevi.

Tietze, A. (2002). Tarihi ve Etimolojik Türkiye Türkçesi Lugatı, Birinci Cilt A-E. (1. Baskı). İstanbul: Simurg Kitapçılık.

Umar, N. (2017). 19. Yüzyılda Adana Vilayeti'ndeki Kamu Yapıları. (Yayımlanmamış doktora tezi). Yıldız Teknik Üniversitesi Fen Bilimleri Enstitüsü, İstanbul.

Weber, S. (2009). Damascus, Ottoman Modernity and Urban Transformation 1808-1918. Vol. 2. (1. Baskı). Aarhus: Aarhus University Press.

Yazıcı Metin, N. (2019). Devlet Kapısı: Tanzimat'tan Cumhuriyet'e Hükümet Konaklarının İnşa Süreci ve Mimarisi. (1. Baskı). İstanbul: Kitabevi Yayınları.

Yerasimos, S. (2012). Tanzimat'ın Kent Reformları Üzerine. Tanzimat, Değişim Sürecinde Osmanlı İmparatorluğu içinde (505-524). İnalcık, H. ve Seyitdanlıŏlu M. (Ed.). İstanbul: Türkiye İş Bankası Kültür Yayınları.

Yılmaz, Ö. F. (2007), Sultan İkinci Abdülhamid Han Devri Osmanlı Mektepleri, Fotoğraf ve Planlar. (1. Baskı). İstanbul: Çamlıca Yayınları.

\section{Internet Kaynakları}

https://www.youtube.com/watch?v=iUR0ap9AcLU, 02.11.2021, 21:45 